KAMIL STACHOWSKI

Jagiellonian University in Kraków

kamil.stachowski@gmail.com

OLAF STACHOWSKI

Jagiellonian University in Kraków

olstach@gmail.com

\title{
POSSIBLY ORIENTAL ELEMENTS IN SLAVONIC FOLKLORE. MAMUNA [PART 1]*
}

Keywords: Slavonic, Oriental, etymology, mythology, folklore

\begin{abstract}
A specialist in Middle Eastern languages will likely be quick to associate Pol. mamuna 'an ape-like mythological creature' with Ar./Pers./Tkc. majmun 'ape'. It is possible and indeed probable that this name is an Oriental borrowing applied to an ancient native belief, but a closer inspection reveals at least several other possibilities tangled in an ethnolinguistic web of potential conflations and contaminations. This paper presents the ethnographic background and some etymological ideas, though without as yet a definite answer.
\end{abstract}

\section{Introduction}

The present paper is concerned with the character and the name of mamuna, an evil spirit that often takes the shape of an ugly, hairy woman who abducts children and places her own in their stead. It is one of just three words apropos which Dźwigoł

* Several researchers were more or less directly involved in the preparation of this paper. In particular, we want to express our gratitude to Prof. Anna Tyrpa and Prof. Barbara Grabka of the Institute of the Polish Language at the Polish Academy of Sciences in Kraków for their cordial help and allowing us access to the library and unpublished materials for Stownik gwar polskich (SGP), and to Vít Boček, PhD, of the Czech Academy of Sciences for Slavist consultation. Needless to say, all remaining errors are ours alone. 
(currenlty perhaps the most comprehensive simultaneously linguistic and ethnographic inquiry into Polish demonological vocabulary) mentions a Turkic language. These three words are: cur (suspected of Turkic origin only in passing; the idea seems to have become quite obsolete by now), upiór (discussed in more detail in Stachowski K., Stachowski O. 2017), and mamuna (Dźwigoł 2004: 115, 66, 164). To find our way between the many red herrings this demon appears to have planted all around herself would require much broader and more detailed data than we have. We will not provide a complete, ready etymology; instead, we will describe the ethnographic and linguistic situation, summarize the state of research, and add some commentary and new ideas to it, hoping for this paper to become in this way a convenient starting point for further exploration.

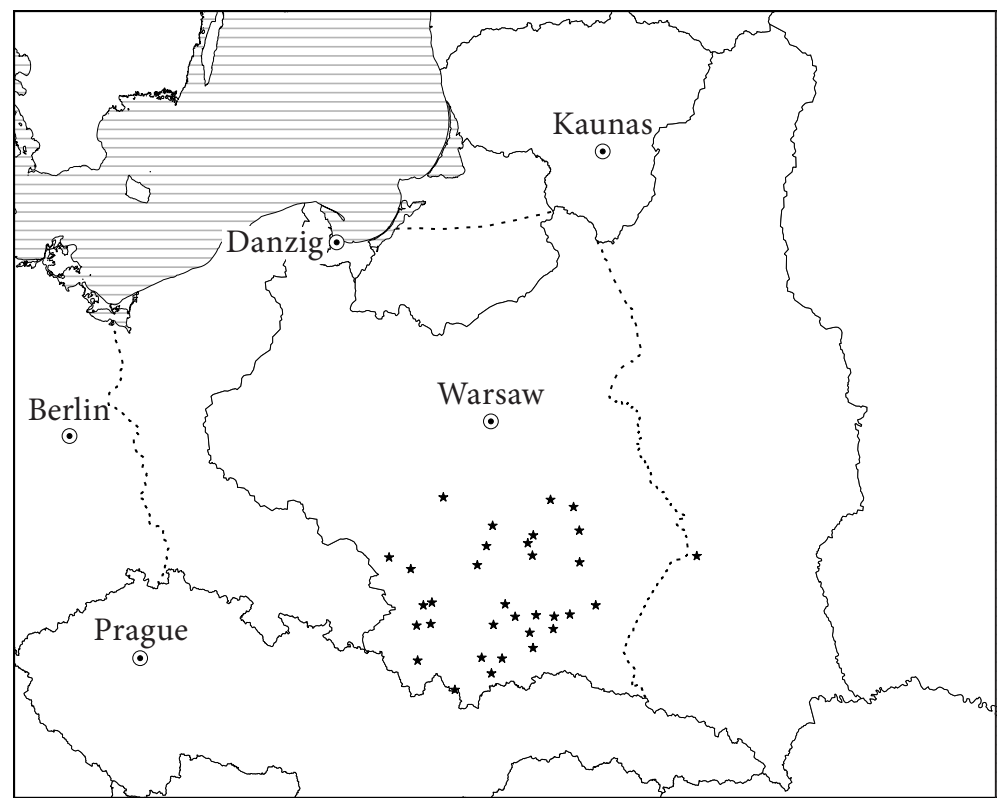

The geographic distribution of mamuna 'an evil spirit' (after Moszyński et al. 1934-1936, vol. 3, map 7), against 1938 borders (De Groot 2010) as those better reflect the reach of Polish population over the past several hundred years than the post-World War II ones

\section{Ethnography}

When reading about the demon known in Polish folklore as mamuna, one encounters mainly two quite inconsistent patterns. One, which we will now elaborate on, is a description of a spirit that looks like an old, hirsute woman with abnormally big and baggy breasts, and whose main function is kidnapping of unguarded children and swapping them for their own (Pełka 1987: 147f). The other, of which we will 
write more in the later part of this section, is the image of the mamuna as a water nymph who lures travellers, especially young men, into lakes or rivers and drowns them (Szyjewski 2003: 177). Both mythologems seem fairly common, though rather mutually exclusive when required to describe one creature; it is our opinion that this apparent discrepancy may be elucidated by a short comparative analysis of the material we have concerning this nowadays fairly forgotten spirit.

Let us begin with a more detailed description of the child-stealing complex. The common motif recorded in the sources is that a human child which is left unattended and unprotected by magico-religious means (the most common ones being tying a red string around the child's wrist or giving it a red cap; the colour red has apotropaic meaning in many cultures of the world due to its connection to life and vitality through the colour of blood; it is also worth noting that it is said that either only unchristened infants are endangered or that they are endangered the most, being preferred by the spirits; cf. Pełka 1987: 15of) may be swapped for a changeling, called odmieniec in Polish. Such a creature, the offspring of the mamuna who swapped it for a human child, is usually exceptionally unruly and loud, though all kinds of abnormal behaviour may be attributed to the child being a changeling (Pełka 1987: 150; Szyjewski 2003: 172). The odmieniec is usually physically disfigured in one way or another, most often an overgrown head is mentioned (Grimm 2007: 364). The child may grow very slowly or not at all, despite exhibiting ravenous hunger (Szyjewski 2003: 172). This belief complex has been usually explained as the folklore interpretation of congenital genetic defects (Szyjewski 2003: 182), allowing both for the explanation of an uncontrollable and very much feared phenomenon as well as for the alleviation of the psychological trauma that may result for the mother, through the setting of the occurrence in a ritualized context. It is also important to note that it is quite common for the mother to feel somehow disconnected from such children, a feeling which is adequately explained by the changeling myth. It is also important to note the traditional ways to make the mamuna give the human child back - most involve either performing ritual purifications, usually by burning herbs (Pełka 1987: 150), surprising the child through unusual behaviour (a similar method is noted in Germany and the Celtic countries where a custom is known of brewing eggshells with the intention to make it speak aloud, and this reveals its nonhuman nature; cf. Yeats 1986: 47; Grimm 2007: 364), or maltreating the changeling to make it cry so that the mamuna returns and takes it back out of pity (Pełka 1987: 150). This last solution to the problem usually involved whipping the child with sticks outside, sometimes having him or her lain on a heap of manure outside the household, which occasionally resulted in the child's death. Such an occurrence may not have been always accidental. It is worth noting (Pełka 1987: 149; Ashliman 1997) that a traditionally emphasized aspect of the belief was always the insatiable hunger of such children, who obviously could not work for themselves and for the family as it was required of its other members in the often starving peasant communities. The belief may then have served (not necessarily in a conscious way on the part of the parents and in general, believers) also as a psychologically-soothing structure allowing for the infanticide of developmentally disabled children whose life endangered 
the other members of the family. Very similar beliefs are well-documented in other European countries too; the understandable psychological background serves in our opinion as a satisfactory explanation of such a widespread distribution, without the need for a monogenetic theory of origin of that myth. It is however worth noting in regard to the last paragraph of this section that the kidnapping of children and putting of changelings in their stead is attributed to elves or trolls (cf. Keightley 1850: 125-126; Hofberg 1893: 176-178) in Scandinavian countries and to fairies in countries with a strong Celtic substrate (cf. Gregor 1881: 60-62; MacDougall 1910: 115-119). This probably quite ancient stratum of such beliefs among Indo-European peoples should be remembered as a comparative background allowing for a better understanding of how the complex may have functioned among the Slavs, who did not leave written records of their religion.

Let us now move on to the idea of the mamuna as a riverbank nymph luring travellers and killing them, usually by drowning. Such an idea is also very common. The difference in the appearance ascribed to the spirit is striking: it is seen as a beautiful young girl, usually naked or clad in a simple white gown (Szyjewski 2003: 171). Its function is also quite different. Some light may be shed on the topic by the comparison of the different names used with reference to creatures of this kind - they are also called, among other names, boginki, dziwożony and wity (Pełka 1987: 93f; Szyjewski 2003: 170), while one of their most popular names among the Eastern Slavonic peoples is русалки. As such, they are one of the most enduring motifs of traditional stories and legends in Russian folklore, which is, incidentally, thought to preserve comparatively more of the original Slavonic mythology than the cultures of Western Slavonic peoples. All these names appear in accounts regarding different female spirits, not necessarily connected with child-stealing but usually retaining a trickster characteristic, luring travellers into dangerous areas or deceiving them (Pełka 1987: 93f). Szyjewski, writing from the standpoint of comparative religion, proposes that those creatures, at first called probably wity or $d z i w y$, originally formed a wide class of female spiritual beings associated with apparently supernatural or anomalous happenings in nature, inhabited the wilderness, especially marshy areas, and were traditionally depicted as beautiful (Gieysztor 1982: 226; Szyjewski 2003: 17of). Boginki under their different names were also associated with circles of evenly-growing plants or mushrooms that are sometimes found in nature, which were explained as the paths in which the spirits had danced and referred to as wiline koła, igrowyszcza (Szyjewski 2003: 173) or czarcie koła. This connection seems noteworthy with regard to our previous argument about the comparison of the idea to the Germanic and Celtic lore - where such phenomena are called fairy rings or elf rings in English (Chambers W., Chambers R. 1841: 55) and Hexenringe or Feenringe in German (HdA s.v. Hexe).

We would like to propose that the mamuna is a comparatively late development of the more ancient wiła/boginka/rusałkaldziwożona complex (which we will henceforth refer to as wiła for the sake of brevity), as one of the more "specialized" spirits into which the wiła complex subsequently split, reflecting the gradual simplification of Slavonic mythology as a result of the chaotic transmission of the lore for want of 
written sources as well as due to the systematic suppression of indigenous beliefs by Church authorities. Such a historical scenario may be reinforced by the fact that the name mamuna is most apparent in Poland and areas that were under Polish cultural influence, while the very same motif of child-swapping is well-known and attributed to wiły in Eastern Slavonic countries (Szyjewski 2003: 172), where the more ancient Slavonic tradition is usually preserved. It is notable too that boginki are linked with child-swapping and conflated with the mamuna in the Kraków region while in the more rural and traditionally conservative Podhale these spirits are seen as distinct (Pełka 1987: 146-152), the mamuna being a specific kind of boginka associated only with child-stealing. We, therefore, think that there may have existed a multi-faceted wiła belief complex which in time split into simplified and distinct stories of different creatures having different characteristics, in a way similar to the transformation of the fairy lore in the Celtic countries. The names and functions of those second-generation creatures may have been conflated and misinterpreted due to the lack of living tradition or textual sources. Specifically, the description of the creature as hirsute and ugly, but decidedly humanlike, may have served as the basis for the conflation with the image of the ape, an equally mythological creature in the eyes of Polish pre-modern village folk and known only through stories of travellers and possibly from the Bible. This may explain the use of małpa 'monkey' with reference to the creature in some regions, reflecting not a different indigenous belief, but a different name under which the (natural) monkey or ape may have been known. Such a historical transformation process is opposite to what was proposed by Pełka, who suggests the mixing and conflation of previously distinct creatures into one internally conflicting image (Pełka 1987: 93), which seems to us less probable considering the widespread distribution of the boginki complex in the Slavonic countries in comparison to the relatively local variation that is mamuna, itself not quite convincing for the very same reason as a relic of an older belief stratum.

\section{References}

Ashliman D.L. 1997. Changelings. [www.pitt.edu/ dash/changeling.html].

Chambers W., Charmbers R. (7 $7^{\text {th }}$ March 1841). Sketches of superstitions. - Chambers' Edinburgh Journal 9: 55-56.

De Groot M. 2010. Building the New Order: 1938-1945. - Spatial History Lab. [web.stanford.edu/ group/spatialhistory/cgi-bin/site/pub.php?id=51].

Dźwigoł R. 2004. Polskie ludowe słownictwo mitologiczne. Kraków.

Gieysztor A. 1982. Mitologia Słowian. Warszawa.

Gregor W. 1881. Notes on the folk-lore of the North-East of Scotland. London.

Grimm J. 2007. [1875-1878]. Deutsche Mythologie. Wiesbaden.

HdA = Hoffmann-Krayer E., Bächtold-Stäubli H. (eds.). 1987. [1927-1942]. Handwörterbuch zur deutschen Volkskunde. Abteilung I. Aberglaube. Berlin, New York.

Hofberg H. 1893. Swedish fairy tales. Chicago.

Keightley T. 1850. Fairy mythology. London.

MacDougall J. 1910. Folk tales and fairy lore in Gaelic and English. Edinburgh. 
Moszyński K. et al. 1934-1936. Atlas kultury ludowej w Polsce. Kraków.

Pełka L.J. 1987. Polska demonologia ludowa. Warszawa.

Stachowski K., Stachowski O. 2017. Possibly Oriental elements in Polish folklore. Upiór wampir. - Németh M., Podolak B., Urban M. (eds.). Essays in the history of languages and linguistics. [Dedicated to Marek Stachowski on the occasion of his $60^{\text {th }}$ birthday]. Kraków: 643-693.

Szyjewski A. 2003. Religia Słowian. Kraków.

Yeats W.B. 1986. Changelings. - Yeats W.B., Gregory I.A., Booss C. (eds.). A Treasury of Irish Myth, Legend, and Folklore. New York: 47-60. 